\title{
초등학생의 $\mathrm{ADHD}$ 성향 유병률과 $\mathrm{ADHD}$ 성향, 환경적 변인들 및 또래관계 간의 관계
}

\section{논문 요약}

본 연구에서는 초등학교 4, 5, 6학년 아동 1429 명을 대상으로 교사보고 자료에 근거하여 $\mathrm{ADHD}$ 성향의 유병 률을 알아보고, 아동이 지각하는 교사의 지지, 또래편견, 부모-학교 협력 및 부모-또래 관심을 환경적 변인으로 선정하여, 이러한 변인들과 $\mathrm{ADHD}$ 성향 및 또래관계 간의 관련성을 살펴보았다. 이를 위해 빈도분석과 독립표본 t검증 및 중다회귀분석을 실시하였다. 연구 결과, 첫째, $\mathrm{ADHD}$ 성향 유병률은 $22.32 \%$ 로 나타났다. 선별된 $\mathrm{ADHD}$ 성향 아동을 학년별로 살펴보면 6학년 아동이 가장 많았고, 남학생이 여학생에 비해 약 3:1의 비율로 더 높게 나타났다. 둘째, $\mathrm{ADHD}$ 성향 아동과 일반 아동 간에 본 연구에서 선정한 환경적 변인들인 교사의 지지, 또래편견, 부모-학교 협력, 부모-또래 관심 및 또래관계에서 유의한 차이가 나타났다. 셋째, 교사의 지지, 또래 편견, 부모-학교 협력, 부모-또래 관심은 $\mathrm{ADHD}$ 성향 아동의 또래관계에 영향을 미치는 것으로 나타났다. 본 연구를 통해 $\mathrm{ADHD}$ 로 진단받진 않았지만 높은 $\mathrm{ADHD}$ 성향을 보이는 아동으로 인해 학교 현장에서의 어려움은 더욱 가중되고 있어, 이들을 조기에 발견하여 적절히 개입하려는 노력이 필요함을 알 수 있었다. 또한 $\mathrm{ADHD}$ 성향 아동도 $\mathrm{ADHD}$ 로 진단받은 아동과 유사하게 또래와의 관계에서 어려움을 경험하고 있으며, 이들의 또래관 계에는 교사, 또래, 부모와 같은 환경 속 요인들이 영향을 미치고 있음을 확인하였다. 본 연구의 결과에 기초하여 논의 및 함의를 제시하였다.

주요어 : $\mathrm{ADHD}$ 성향, 유병률, 환경적 맥락, 또래관계, 초등학생

* 부산대학교 교육발전연구소 전임연구원 


\section{I. 서론}

주의력결핍 및 과잉행동-충동성 장애(Attention Deficit Hyperactivity Disorder: 이하 ADHD) 는 학령기 혹은 학령전기에 가장 흔하게 나타나고 있는 아동 - 청소년 정신장애 중 하나로, 주의 력결핍, 과잉행동 및 충동성을 임상적 특징으로 하는 일련의 행동으로 정의된다(American Psychiatric Association: APA, 2013). ADHD의 유병률에 대해서는 학자들마다 다른 결과를 보 이지만 대략 학령기 아동의 3 7\%로 추정되고 있으며, 보통 남아가 여아에 비해 약 3배 정도 더 높은 것으로 보고되고 있다(Barkley, 2006).

$\mathrm{DSM}-5$ 에 의하면 $\mathrm{ADHD}$ 로 진단받기 위해서는 부주의나 과잉행동·충동성의 증상들 중에서 6 개 이상의 증상이 6개월 이상, 2가지 이상의 장면에서 지속적으로 나타나야 한다(APA, 2013). 이에 대해 몇몇의 선행연구들은 6 개 혹은 그 이상의 증상을 나타내는 아동이 5 개 혹은 4 개의 증상을 나타내는 아동보다 기능적으로 더 손상되었다고 볼 수 있는가 하는데 대한 의문을 제기 하고 있다. $\mathrm{ADHD}$ 의 진단 기준을 충분히 채우지 못한다 할지라도 $\mathrm{ADHD}$ 로 진단받은 경우와 비슷한 수준의 심리사회적 손상이 나타나고 있다는 것이다(Cho et al., 2009; Rohde, 2008). 이와 유사하게 여러 선행연구들을 통해 $\mathrm{ADHD}$ 로 진단받거나 병원에 의뢰될 수준은 아니지만 높은 $\mathrm{ADHD}$ 성향을 보이는 아동에게서 학교부적응, 우울, 인터넷 중독과 같은 부적응적 문제가 확인 되고 있다(김홍석, 이동훈, 송연주, 2013; 이동훈, 2009, 2011; 최진오, 2012; Lewinsohn, Shankman, Gau, \& Klein, 2004; Yoo et al., 2004). 이러한 점에서 ADHD로 진단받진 않았지만 이와 유사한 정도나 수준의 증상을 보이는 $\mathrm{ADHD}$ 성향 아동(Cho et al., 2009)에 대한 관심이 높아지고 있다.

$\mathrm{ADHD}$ 성향 아동의 유병률은 $\mathrm{ADHD}$ 로 진단 받은 아동의 유병률과 비교했을 때 유사하거나 조금 더 높게 나타나고 있다. 초등학교 1 6학년 아동 6,372명의 자료를 분석한 표경식 등(2001) 의 연구에 의하면 $6.1 \%$ 의 아동이 ADHD 성향을 나타냈으며, 이동훈(2009)은 초등학생 4 6학년 아동 218 명의 자료 가운데 $9.6 \%$ 의 아동이 $\mathrm{ADHD}$ 성향을 보이는 것으로 보고하였다. Cho 등 (2009)은 초등학생 2,493명 가운데 $\mathrm{ADHD}$ 성향 아동의 유병률을 약 9.0\%로 보고하였다. 2010년 경기도와 경기도교육청은 경기도 내 초등학교 신입생 8 만9629명 가운데 $11.4 \%$ 인 1만212명을 $\mathrm{ADHD}$ 성향 아동으로 분류하였다(서울신문, 2010.08.26). 이 같은 유병률은 한 학급에 1 2명은 $\mathrm{ADHD}$ 성향을 나타낼 수 있음을 제시하는 것으로, 이들이 적절한 개입이나 치료를 제공받지 못한다면 $\mathrm{ADHD}$ 로 진단되거나 또 다른 형태의 이차적 문제를 나타낼 가능성이 매우 높을 수 있다(Cho et al., 2009). 따라서 높은 수준의 $\mathrm{ADHD}$ 증상을 보이는 $\mathrm{ADHD}$ 성향 아동에 대한 올 바른 이해와 인식이 필요하다.

$\mathrm{ADHD}$ 성향 아동의 특성에 대한 이해는 $\mathrm{ADHD}$ 아동의 특성을 통해 가능하다. $\mathrm{ADHD}$ 아동 
이 보이는 증상이나 문제의 심각성이 가장 두드러지는 곳은 학교 안이다. 학교는 아동에게 정해 진 시간에 자리에 앉아 조직화된 과제를 수행하게 하고, 높은 수준의 사회적 행동을 요구하기 때문에 $\mathrm{ADHD}$ 와 관련된 여러 적응상의 문제가 그 어느 곳보다 직접적으로 드러나게 된다(이정 은, 김춘경, 2009). 이로 인해 교사들의 효과적인 수업 운영과 또래 아동들의 학교생활에의 어려 움은 더욱 가중되고 있고, $\mathrm{ADHD}$ 아동 스스로도 학교 안에서 다양한 어려움을 경험하고 있다. 그 가운데서 가장 큰 어려움 중 하나는 또래관계 문제일 것이다. 이들의 과잉행동적이고 충동적 인 행동 특성은 또래의 놀이나 수업을 방해하고 자기주장이 강해 또래와 잦은 갈등을 일으킨다. 이들은 주의력이 떨어져 대화에 잘 참여하지 못하고 대화의 내용도 잘 기억하지 못하며 수줍어 한다. 이로 인해 대다수의 $\mathrm{ADHD}$ 아동이 또래거부를 경험하는 것으로 보고되고 있다(Hoza, 2007). 일반 아동을 대상으로 한 연구에서도 $\mathrm{ADHD}$ 성향이 높을수록 또래로부터 더 많은 거부 를 경험하고 있고(Diamantopoulou, Henricsson, \& Rydell, 2005), ADHD 성향 아동이 일반 아 동에 비해 논쟁을 하거나 다투는 등의 대립적인 관계 형성을 더 많이 하는 것으로 나타나(이동 훈, 2011), $\mathrm{ADHD}$ 성향 아동 또한 $\mathrm{ADHD}$ 아동과 유사하게 또래관계에서 어려움을 경험하고 있 는 것으로 확인되고 있다.

또래거부와 같은 또래문제는 비교적 지속적이어서, 또래거부를 경험한 $\mathrm{ADHD}$ 아동은 청소년 기 및 성인기에 이르기까지 반사회적 행동, 약물 중독, 비행, 우울 및 불안을 경험할 확률이 매우 높다(Murg et al., 2012). 아동이 $\mathrm{ADHD}$ 와 또래거부를 동시에 경험하게 되면, $\mathrm{ADHD}$ 나 또래거 부 중 하나만 경험하는 것보다 훨씬 더 높은 수준의 이차적 문제를 경험하는 것으로 나타나고 있다(Mikami \& Hinshow, 2006). 최근 들어서는 ADHD와 학교폭력 간의 관련성도 대두되고 있 다(신동원, 이승민, 2009; 최진오, 2012; Holmberg \& Hijern, 2008). 이들의 높은 공격성이 또래가 해로 이어지면서 집단따돌림이나 왕따와 같은 또래피해를 경험하게 된다. 계속된 또래거부로 인 해 경험하게 되는 외로움이나 불안, 분노, 좌절감 등이 쌓이면 폭력적인 행동으로 표출될 위험도 배제할 수 없다(이희정, 황선영, 2013). $\mathrm{ADHD}$ 아동이 피해자이면서 가해자로서의 관계를 동시 에 경험하게 되면 피해자이거나 가해자이기만 한 $\mathrm{ADHD}$ 아동에 비해 또래로부터 더 많은 거절 과 갈등을 경험하는 것으로도 보고되고 있다(Wiener \& Mak, 2009). 이러한 점으로 미루어 볼 때 $\mathrm{ADHD}$ 아동뿐만 아니라 $\mathrm{ADHD}$ 성향을 가진 아동의 또래관계 어려움에 관심을 가지고, 이를 증진시켜 주기 위한 개입 방안 마련이 필요하다 하겠다.

지금까지 $\mathrm{ADHD}$ 아동의 또래관계 증진을 위해서는 다양한 방면에서의 노력이 있어왔다. 이 들의 $\mathrm{ADHD}$ 성향이나 공격성을 감소시키고 부족한 사회기술을 길러주기 위해 다양한 개입이 시행되어 긍정적인 효과를 가져왔지만, 이들의 또래관계를 개선시키는 데는 한계가 있었다(de Boo \& Prins, 2007). ADHD 아동의 또래관계 증진을 위한 아동대상 개입만으로는 치료 장면에 서의 효과가 일상생활에까지 이어지지 않았고, 치료를 통해 또래로부터 거부당했던 행동을 더 
이상 보이지 않는다 해도 또래거부는 계속되었다(Hoza et al., 2005; McQuade \& Hoza, 2008). 이러한 한계점을 극복하기 위해 아동이 생활하는 일상에서 치료가 이루어져야 한다는 주장이 제기되면서(DuPaul \& Weyandt, 2006), $\mathrm{ADHD}$ 아동의 또래관계 어려움을 아동이 속해 있는 환 경 속에서 풀어가려는 움직임이 일게 되었다. 생태학적 관점에서는 환경적 맥락에서 벗어난 개 인의 발달은 이루어질 수 없음을 강조한다. 즉, 개인의 발달은 개인의 특성뿐만 아니라 개인을 둘러싸고 있는 환경과 그 환경 간의 상호작용을 통해 일어난다는 것이다(Bronfenbrenner, 1979). 이 같은 관점에서 미루어볼 때도 $\mathrm{ADHD}$ 아동의 또래관계를 보다 깊이 이해하기 위해서는 아동 을 둘러싸고 있는 환경적 맥락에서의 이해가 필요함을 알 수 있다.

$\mathrm{ADHD}$ 아동이 속해 있는 주된 환경으로 학교와 가정을 들 수 있는데, 그 중에서 학교는 학령 기 아동이 가장 많은 시간을 보내는 곳이라 할 수 있다. 학교 내에서 일어나는 많은 상호작용들 은 학교 안의 교사와 학생들 간의 상호관계 속에서 이루어지는데, 이 때 교사가 아동과 맺는 긍 정적인 관계는 아동이 또래와 더 많은 상호작용을 하게 한다(Mikami, Lerner, \& Lun, 2010). $\mathrm{ADHD}$ 아동의 말과 행동은 또래로부터 매우 부정적인 반응을 불러일으키기 쉽다. $\mathrm{ADHD}$ 아동 을 향해 한 번 형성된 부정적인 편견은 $\mathrm{ADHD}$ 아동의 행동 변화에도 불구하고 쉽게 사라지지 않고 오랫동안 지속되는 경향이 있다. 이로 인해 $\mathrm{ADHD}$ 아동이 부정적인 말이나 행동을 더 이 상 보이지 않는다 해도, 이들을 향한 또래거부는 지속될 수 있다(Hoza et al., 2005). 이와 더불어 $\mathrm{ADHD}$ 아동을 위한 교육의 성공을 위해서는 학교와 가정에서의 상호보완적이고 지속적인 협력 관계가 매우 중요하다(황순영, 2011). 부모와 교사, 혹은 부모와 또래가 가정과 학교라는 두 환경 에서 아동의 양육과 교육에 상호 도움을 주고받음으로써 $\mathrm{ADHD}$ 아동의 학교적응(Pfiffner, Villodas, Kaiser, Rooney, \& McBurnett, 2013)을 비롯하여 이들의 사회성 발달에도 영향을 미치 는 것으로 보고되고 있다(이미아, 2008).

이러한 점에서 본 연구에서는 $\mathrm{ADHD}$ 성향 아동의 또래관계 어려움을 환경적 맥락에서 살펴 보고자 하였고, 이를 위해 교사의 지지와 또래편견 및 부모-교사 협력, 부모-또래 관심을 환경적 변인으로 설정하였다. $\mathrm{ADHD}$ 성향 아동의 또래관계 어려움에 있어서 이러한 환경적 변인들의 영향력이 확인된다면, $\mathrm{ADHD}$ 성향 아동의 또래관계 증진을 위해 교사나 또래와 같은 학교 내 환경적 맥락과 더불어 학교와 가정 간의 협력 관계를 고려해야 함을 알 수 있을 것이다. 본 연구 를 통해 $\mathrm{ADHD}$ 성향 아동에 대한 올바른 이해와 인식을 바탕으로, 이들의 또래관계 어려움을 감소시켜주기 위한 개입 방안 마련에 있어 환경적 측면에서의 보다 실질적이고 구체적인 교육 및 개입이 시행되기를 기대해본다.

본 연구에서 다루고자 하는 연구문제들은 다음과 같다.

첫째, 초등학생의 $\mathrm{ADHD}$ 성향 유병률을 어떠한가?

둘째, $\mathrm{ADHD}$ 성향 아동과 일반 아동 간의 교사의 지지, 또래편견, 부모-교사 협력, 부모-또래 
관심 및 또래관계에 차이가 있는가?

셋째, 초등학생의 $\mathrm{ADHD}$ 성향과 교사의 지지, 또래편견, 부모-교사 협력, 부모-또래 관심 및 또래관계 간의 관계는 어떠한가?

\section{ㅍ. 이론적 배경}

\section{1. 초등학생의 $\mathrm{ADHD}$ 성향 유병률}

$\mathrm{ADHD}$ 성향 아동의 유병률에 있어서 성별에 따른 차이가 나타나고 있다. $\mathrm{ADHD}$ 성향 아동 들 중에서 표경식 등(2001)은 남학생은 $8.3 \%$, 여학생은 $3.9 \%$ 로 보고하였으며, Cho 등(2009)은 남학생이 여학생에 비해 약 6:1의 비율로 높은 것으로 보고하였다. 이동훈(2009)의 연구에 의하 면 남학생은 $11.2 \%$, 여학생은 $8.1 \%$ 로 나타났다. 이는 남아는 임상장면에 의뢰될 만큼의 공격성 이나 행동 문제를 나타내지만, 여아는 남아만큼의 공격성이나 행동 문제를 보이지 않아 임상장 면에 덜 의뢰되었을 가능성이 큰 것으로 해석할 수 있다(Cho et al., 2009). 비록 여아가 남아에 비해 낮은 유병률을 보이지만, $\mathrm{ADHD}$ 유형이나 증상의 정도에 있어서는 남녀 간 큰 차이가 없 고, 오히려 우울이나 불안과 같은 내현화 증상에 있어서는 여아가 남아에 비해 더 많은 손상을 보이는 것으로도 보고되고 있다(Rucklidge \& Tannock, 2001).

선행연구들에 의하면 주의력결핍 증상은 연령이 증가하더라도 지속적으로 남아있지만, 과잉 행동·충동 증상들은 연령이 증가할수록 감소된다고 알려져 있다(Cantwell, 1999; DuPaul et al., 1997; Jeong et al., 2001). 이처럼 $\mathrm{ADHD}$ 아동의 절반 정도는 청소년기가 되기 전 과잉행동이 많이 줄어드는 것으로 알려져 있지만, 성인기에도 과잉행동 증상들이 계속해서 보고된다는 주장 (Weiss \& Hechtman, 1993)도 있다. 이와 더불어 과거에는 $\mathrm{ADHD}$ 가 아동기 특유의 장애로, 청소 년기에 감소하기 시작하여 성인기에 이르면 약해지는 것으로 인식되어 왔으나 1990년대 이후 들어 $\mathrm{ADHD}$ 아동의 $65 \sim 80 \%$ 가 사춘기와 성인기에 이르러서도 여전히 진단기준을 충족시키고 있는 것으로도 확인되고 있다(Fischer, Barkley, Smallish, \& Fletcher, 2005). ADHD로 인한 문제 가 아동기에 해결되지 않고 청소년기나 성인기로 이어질 경우 품행장애, 반사회적 인격장애, 중 독 등의 문제로 이어질 가능성도 매우 높은데(Fischer et al., 2005; Murg et al., 2012), ADHD 성향 아동 또한 적절한 개입이나 치료가 이루어지지 않는다면 $\mathrm{ADHD}$ 로 진단되거나 또 다른 형 태의 장애로 이어질 가능성도 매우 높은 것으로 나타나고 있다(Cho et al., 2009). 따라서 ADHD 성향 아동의 유병률 조사 및 원인에 대한 연구가 지속되어, $\mathrm{ADHD}$ 성향 아동을 위한 정책 수립 및 중재 방안 마련에 기초자료로 활용되어야 할 것이다. 


\section{2. 초등학생의 $\mathrm{ADHD}$ 성향과 또래관계와의 관계}

$\mathrm{ADHD}$ 아동은 또래관계에서 많은 어려움을 경험한다. 이들의 부주의하고 충동적이며 공격적 인 행동 특성이나 부족한 사회기술은 타인과의 적절한 관계 형성을 어렵게 한다. 이들은 대화에 서 사람들의 표정이나 말의 의미를 제대로 해석하지 못해 엉뚱한 대답을 하거나 대화 내용을 잘 기억하지 못한다. 또한 늘 자신에게 익숙한 대로 행동하기 때문에 주변상황에 대해 적절한 태도와 반응을 취하기 어렵다(Huang-Pollock, Mikami, Pfiffner, \& McBurnett, 2009). ADHD 아 동의 과잉행동·충동 성향은 타인으로부터의 제재를 받으려 하지 않고 남의 말을 잘 들으려 하지 않는다. 이들은 대인관계에서 일반 아동에 비해 공격적 태도로 상호작용하는 경우가 잦고, 감정 조절이 어려워 자신의 기분이 좋고 나쁨을 과도하게 표현함으로서, 관계에서 많은 어려움을 경 험한다(Hodgens, Cole, \& Boldizar, 2000).

$\mathrm{ADHD}$ 성향 아동 또한 $\mathrm{ADHD}$ 아동과 유사하게 또래관계에서 어려움을 경험하는 것으로 보 고되고 있다. Diamantopoulou 등(2005)에 의하면, $\mathrm{ADHD}$ 성향과 또래거부 간 정적인 상관관계 가 나타났다. 이는 $\mathrm{ADHD}$ 성향이 높을수록 또래로부터 더 많은 거절을 경험함을 의미한다고 볼 수 있다. 이동훈(2011)의 연구에서는 $\mathrm{ADHD}$ 성향 아동과 일반 아동 집단 간 또래관계에서 유의한 차이가 나타났다. 또래와의 관계를 형성함에 있어 $\mathrm{ADHD}$ 성향 아동이 일반 아동에 비해 서로 뜻이 맞지 않아 화를 내거나, 의견이 일치되지 않아 다투거나 논쟁하는 등의 모습에서 차이 가 나타나, 이들이 또래와 의견 조절이 잘 이루어지지 않고 효과적인 의사소통을 하지 못하고 있음을 추측할 수 있다. 이와 같은 연구결과들은 $\mathrm{ADHD}$ 로 진단받진 않아도 이와 유사한 증상을 보이는 $\mathrm{ADHD}$ 성향 아동 또한 $\mathrm{ADHD}$ 로 진단받은 아동과 동일하게 또래와의 관계에서 어려움 을 경험하고 있음을 제시한다고 볼 수 있다.

최근에는 $\mathrm{ADHD}$ 로 진단받은 아동이나 $\mathrm{ADHD}$ 성향을 가진 아동은 자신들의 행동 특성으로 인해 일반 아동에 비해 학교폭력을 경험하게 될 확률이 매우 높은 것으로도 보고되고 있다(신동 원, 이승민, 2009; 최진오, 2012; Holmberg \& Hijern, 2008). 따라서 ADHD 성향 아동의 또래관 계 어려움에 대한 보다 명확한 원인 규명을 통해 실질적이고 구체적인 개입을 실행하기 위해 노력해야 할 것이다.

\section{3. 초등학생의 $\mathrm{ADHD}$ 성향과 환경적 변인들 및 또래관계 간의 관계}

$\mathrm{ADHD}$ 아동의 또래관계 어려움에 대해서는 다양한 연구가 이루어져 왔다. $\mathrm{ADHD}$ 의 핵심증 상이나 공격성, 부족한 사회기술로 인해 또래관계에서 어려움을 경험할 수 있어, 이러한 개인적 특성을 변화시켜주기 위한 개입이 시행되었다. 그러나 이러한 개입은 $\mathrm{ADHD}$ 아동의 관계 개선 
에 있어 부분적인 효과만을 가져올 뿐, 궁극적인 해결책은 되지 못했다. 무엇보다도 치료 장면에 서의 효과가 일상생활에까지 이어지지 못했던 것이다(de Boo \& Prins, 2007). 이러한 한계점을 보완하기 위해 $\mathrm{ADHD}$ 아동의 또래관계 문제는 이들의 일상생활 환경에서 다루어져야 한다는 주장이 제기되었다. 이들에게 있어 일상생활 환경이란 가정이나 학교가 될 것이기에, 학교라는 장면에서 개입이 이루어지거나, 학교와 가정과의 협력이 이루어짐으로써 이들의 또래관계 증진 을 이루고자 한 것이다(DuPaul \& Weyandt, 2006). 그 결과, $\mathrm{ADHD}$ 아동만을 대상으로 실시하 거나, 부모나 교사만을 대상으로 할 때보다 아동의 사회기술 증진에 보다 더 큰 긍정적 효과가 나타났으며, 이러한 긍정적 효과가 가정이나 학교상황으로까지 연계될 수 있는 가능성을 보여주 었다(장은진, 2005; DuPaul \& Weyandt, 2006; Hoza et al., 2005; Mikami Jack, Emeh, \& Stephens, 2010; Pfiffner et al., 2013). 즉, $\mathrm{ADHD}$ 아동의 또래관계 증진을 위해서는 이들에게 상황에 맞는 적절한 행동과 친 사회적 기술을 가르치는 것도 중요하지만, 교사, 또래, 부모와 같 은 사회적 환경의 변화를 동시에 고려해야 함을 알 수 있다.

$\mathrm{ADHD}$ 아동이 속한 사회적 환경의 변화를 위해서는 $\mathrm{ADHD}$ 아동과 환경 간 상호작용을 확인 하여 또래관계에서의 갈등을 일으키는 관계를 변화시키기 위한 적절한 지원 방안이 마련되어야 한다. 학교 내에서 일어나는 많은 상호작용들은 학교에서 함께 생활하는 교사와 학생, 그리고 학생들 간의 상호관계 속에서 이루어진다. 교사의 중재는 $\mathrm{ADHD}$ 아동의 증상 완화 및 교실 내 긍정적인 행동 증가와 관련이 있다(Miranda, Presentaction, \& Soriano, 2002). 교사와 학생 간의 긍정적인 관계는 학생의 사회적 역량을 높여주고 또래들 사이에서 더 많은 사회적 상호작용을 일으켰으며(Mikami, Lerner et al., 2010), 아동의 산만한 행동을 감소시켰다(Mikami, Gregory, Allen, Pianta, \& Lun, 2011). 이러한 연구결과에 비추어 볼 때, 교사가 ADHD 성향 아동의 또래 관계에 미치게 될 영향력을 충분히 엿볼 수 있다.

$\mathrm{ADHD}$ 아동의 경우, 이들이 훈련을 통해 친사회적 행동을 습득하여 또래로부터 거절당했던 부정적인 행동을 더 이상 보이지 않는다 해도 또래거부는 지속되었다(Hoza et al., 2005). 이는 $\mathrm{ADHD}$ 아동을 향한 또래의 부정적인 평판이 $\mathrm{ADHD}$ 아동의 변화된 행동에도 쉽게 바뀌지 않음 을 제시한다고 볼 수 있다. $\mathrm{ADHD}$ 로 진단받았거나 이와 유사한 증상을 보이는 아동을 향해서는 사회적 거리를 두게 되고 덜 친근하게 대하며 더욱더 부정적인 평가를 가하기 쉬운데, $\mathrm{ADHD}$ 아동 또한 자신이 교실 내에서 다른 또래들과 다르게 취급당하는 것으로 인식하고 있었다 (Wiener et al., 2012). 즉, $\mathrm{ADHD}$ 로 진단받는 것 자체가 이미 사회적으로 편견을 갖게 하고, $\mathrm{ADHD}$ 로 인해 나타나는 증상에 대해 또래가 편견을 가지고 대하는 것으로 가정할 수 있다.

$\mathrm{ADHD}$ 아동에게 있어서의 교육적, 행동적 중재의 효과는 가정과 학교의 협력을 통해 더욱 증진될 수 있다(황순영, 2011). 부모-학교 협력이란 부모가 자녀의 학교 교육을 지원하는 정도를 의미하는 것으로, 부모와 교사가 서로 협력하여 정보를 교류하고 이를 바탕으로 양육과 교육에 
상호 도움을 제공받을 수 있다. 부모와 학교 간 관계가 좋을수록 자녀가 또래들 사이에서 좋아하 는 친구로 지명되는 횟수도 증가하였고(도금혜, 최보가, 2007), 부모-학교 협력이 ADHD 아동의 사회적 유능성에도 영향을 미치는 것으로 보고되고 있다(이미아, 2008).

부모-또래 관심이란 부모가 자녀의 또래관계에 가지는 관심과 지지를 의미한다. 부모가 자녀 를 또래와 만날 수 있는 과외활동에 등록시켜 사회적 상호작용을 가지게 함으로서 1년 후 아동 의 또래수용도가 높아졌고(McDowell \& Parke, 2009), 부모와 또래 간 관계가 좋을수록 또래로 부터 좋아하는 친구로 지명 받는 횟수도 증가하였다(도금혜, 최보가, 2007). 일반 아동에 비해 $\mathrm{ADHD}$ 아동의 부모는 친구를 집으로 초대하는 횟수가 훨씬 적은 것으로 나타나(Mikami, Jack et al., 2010), 부모가 ADHD 성향 아동의 또래 친구에게 보이는 행동이나 관심이 이들의 또래관 계에 영향을 미칠 수 있음을 추측해 볼 수 있다.

종합해보면 아동을 둘러싸고 있는 환경 및 환경들 간의 상호 관계나 협력이 $\mathrm{ADHD}$ 성향 아동 의 또래관계에 영향을 미칠 것으로 추측할 수 있다. 그러나 지금까지 환경적 맥락에서 $\mathrm{ADHD}$ 성향 아동의 또래관계를 살펴본 연구는 많지 않다. $\mathrm{ADHD}$ 와 관련된 적응상의 문제가 학교라는 장소에서 가장 두드러질 수 있고(이정은, 김춘경, 2009), 관계는 개별적 요인에 의해서라기보다 변인들 간의 상호작용에 의해서도 발생할 수 있는 것이라는 점에서(Antshel, 2005), 학교 내 이러 한 환경적 변인들 간 관계가 $\mathrm{ADHD}$ 성향 아동의 또래관계에 미치는 영향을 종합적으로 살펴볼 필요가 있다.

\section{III. 연구 방법}

\section{1. 연구대상 및 연구절차}

본 연구는 $\mathrm{B}$ 시 및 $\mathrm{K}$ 지역에 소재한 9 개 초등학교의 $4,5,6$ 학년 56 개 학급의 아동들이 참여하였 다. 아동에게 배부된 설문지는 총 1512 부였고, 이 가운데 1435 부가 회수되었다. 설문을 실시하기 전에 연구자가 교사에게 연구 목적, 설문 절차, 설문 중 유의사항 등에 관한 오리엔테이션을 실 시하거나, 별도의 안내문을 첨부하여 설문 실시에 어려움이 없도록 하였다. 아동들은 교사의 지 지, 또래편견, 부모-학교 협력, 부모-또래 관심 척도에 응답하였다. 본 연구가 연구대상을 초등학 교 고학년만으로 선정한 이유는 아동의 자기보고식 자료에 근거하고 있어서이다. 초등학교 아동 의 자기 개념은 연령이 높아지면서 발달하기 때문에(Harter, 2012), 초등학교 저학년의 경우 자 기 행동과 정서에 대한 지각이 낮을 것으로 판단하였다.

설문지는 담임교사에게도 동일하게 1512 부가 배부되었고, 1430 부가 회수되었다. 담임교사는 
담임을 맡고 있는 아동들에 대한 관찰을 토대로 교사용 $\mathrm{ADHD}$ 평가 척도에 응답하도록 하였다. $\mathrm{ADHD}$ 를 선별함에 있어서 교사의 평정은 매우 중요하다. $\mathrm{ADHD}$ 와 관련된 핵심증상이나 적응 상에서 나타나는 여러 문제들은 구조화된 환경인 학교에서 더욱 두드러질 수 있어, 아동을 그 누구보다 잘 관찰할 수 있고 다른 아동과의 직접적인 비교가 가능한 담임교사의 평가는 매우 핵심적일 수 있다. 부모의 경우 아동에 대한 기초적인 정보를 제공할 수는 있지만 교사와 달리 비교대상이 없어 객관성이 다소 미흡할 수 있다고 판단하여(송수미, 김재환, 2002), 본 연구에서 는 교사보고를 활용하였다.

학생과 교사로부터 회수된 설문지 중 불성실한 응답을 제외한 1429 명의 자료를 최종 분석에 사용하였다. 연구대상은 남학생이 733명(51.3\%), 여학생이 696명(48.7\%)을 차지하였고, 학년별로 는 4학년 541명(37.9\%), 5학년 453명(31.7\%), 6학년 435명(30.4\%) 이었다.

\section{2. 측정도구}

\section{1) $\mathrm{ADHD}$ 평가 척도}

본 연구에서는 $\mathrm{ADHD}$ 성향 아동을 평가하기 위해 $\mathrm{DuPaul}(1991)$ 의 교사용 $\mathrm{ADHD}$ 평가 척도를 소유경 등(2002)이 번안하고, 김영신 등(2003)이 표준화한 한국판 교사용 $\mathrm{ADHD}$ 평가 척도 (K-ARS)를 사용하였다. K-ARS는 주의력결핍과 과잉행동충동성의 2개 하위척도로 구성되었으며, 각각 9 문항씩 총 18 문항으로 이루어져 있다. 각 문항은 아동의 문제행동의 빈도에 따라 0 점 “전혀 그렇지 않다"에서 3점 "매우 그렇다"까지의 4점 리커트 척도로 평정하게 되어 있다. 교사용의 경 우는 17점 이상을 $\mathrm{ADHD}$ 성향을 나타내는 것으로 간주한다(김재원, 박기홍, 최민정, 2004). 신뢰도 (Cronbach's $\alpha$ )는 소유경 등(2002)의 연구에서 주의력결핍은 .77 . 87 , 과잉행동충동은 .78 . 87 로 나타났고, 본 연구에서는 주의력결핍 .96, 과잉행동충동 .96, 총합은 .97 로 나타났다.

\section{2) 교사의 지지}

본 연구에서는 교사의 지지를 평가하기 위해 Dubow와 Ulman(1989)이 개발한 초등학교 아동 의 사회적 지지 척도(Social Support Appraisal Scale)와 Harter(1985)의 아동용 사회적 지지 척 도(Social Support Scale for Children)를 한미현(1996)이 수정 보완한 사회적 지지 척도 중 교사 의 지지에 해당하는 문항만을 사용하였다. 사회적 지지 척도는 가족지지(8문항), 또래지지(8문 항), 교사지지(8문항)에 대한 아동의 지각이나 평가를 측정하는 도구로, 총 24 문항으로 구성되어 있다. 각 문항은 0 점 “전혀 그렇지 않다"에서 4 점 "항상 그렇다"까지의 5 점 리커트 척도로 평정 
하게 되어 있다. 한미현(1996)의 연구에서 교사의 지지 신뢰도(Cronbach's $\alpha$ )는 .88이었고, 본 연구에서는 .88 로 나타났다.

\section{3) 또래편견}

본 연구에서는 $\mathrm{ADHD}$ 아동이 또래에게 느끼는 편견을 평가하기 위해 Kaidar와 Wiener 및 Tannock(2003)이 개발한 $\mathrm{ADHD}$ 귀인 척도(Attributions for $\mathrm{ADHD}$ questionnaire: $\mathrm{AAQ}$ ) 중에 서 또래로부터의 낙인을 묻는 3문항을 연구자가 번안하여 사용하였다. AAQ 척도는 부모로부터 느끼는 낙인감(3문항), 교사로부터 느끼는 낙인감(2문항), 또래로부터 느끼는 낙인감(3문항)과 아동 스스로 느끼는 낙인감(2문항)의 총 10 문항으로 구성되어 있다. 각 문항은 0점 “전혀 그렇지 않다"에서 2점 “매우 그렇다"까지의 3점 리커트 척도로 평정하게 되어 있다. 신뢰도(Cronbach's $\alpha)$ 는 Kaidar 등(2003)의 연구에서 .76으로, 본 연구에서는 .77로 나타났다.

\section{4) 부모-학교 협력}

부모-학교 협력을 측정하기 위해 정계숙(1990)과 최명선(1998)의 가정-학교 관계 척도를 도금 혜(2007)가 수정하고 김은미(2012)가 다시 수정한 척도를 사용하였다. 본 척도는 부모의 학교활 동 참여, 자녀의 학교생활에 대한 관심, 담임교사의 의견 수용을 묻는 4 문항으로 이루어져 있다. 각 문항은 0점 “전혀 그렇지 않다"에서 3점 “매우 그렇다"까지의 4점 리커트 척도로 평정하게 되어 있다. 신뢰도(Cronbach's $\alpha$ )는 김은미(2012)의 연구에서 .76으로, 본 연구에서는 .77로 나 타났다.

\section{5) 부모-또래 관심}

부모의 또래 관심을 측정하기 위해 본 연구에서는 Mounts(2000)의 연구를 바탕으로 박민정 (2002)이 제작한 가정-또래관계 척도를 사용하였다. 본 척도는 자녀의 친구에 대한 관심, 친구 이름 인지, 친구와의 활동에 대한 인지 및 지지 여부를 포함한 총 6문항으로 이루어져 있다. 각 문항은 0점 “전혀 그렇지 않다”에서 3점 “매우 그렇다”까지의 4점 리커트 척도로 평정하게 되어 있다. 신뢰도(Cronbach's $\alpha$ )는 박민정(2002)의 연구에서 .62로, 본 연구에서는 .63으로 나타났다. 
6) 또래관계

본 연구에서 $\mathrm{ADHD}$ 성향 아동의 또래관계를 측정하기 위해 양윤란과 오경자(2005)가 개발한 또래관계기술척도를 사용하였다. 본 척도는 주도성과 협동/공감의 두 하위요인으로 나뉘며, 총 19 문항으로 구성되어 있다. 각 문항은 1점 “전혀 없었다" 에서 4점 “항상 그렇다"까지의 4점 리 커트 척도로 평정하게 되어 있다.

$\mathrm{ADHD}$ 아동은 일반 아동에 비해 사회기술이 부족하여 또래관계에서 어려움을 경험하는데, 아동과 청소년의 사회기술을 구성하는 가장 중요한 차원으로 또래관계기술을 들 수 있다. 또래 관계기술이란 또래수용이나 또래거부와 같은 사회적 행동을 예측하게 하는 행동으로(양윤란, 오 경자, 2005), 또래관계기술을 통해 아동의 또래관계를 예측할 수 있다. 이에 본 연구에서는 또래 관계기술을 측정하여 또래관계를 살펴보았다. 신뢰도(Cronbach's $\alpha$ )는 양윤란과 오경자(2005) 의 연구에서 .81로, 본 연구에서는 .91로 나타났다.

\section{3. 자료 분석 방법}

본 연구에서는 다음과 같은 방법으로 분석하였다.

첫째, 초등학생의 $\mathrm{ADHD}$ 성향 유병률을 알아보기 위해, 교사용 $\mathrm{K}-\mathrm{ARS}$ 척도의 진단 기준인 17 점 이상의 아동을 $\mathrm{ADHD}$ 성향 아동으로 분류하여 빈도분석을 실시하였다. 분류된 $\mathrm{ADHD}$ 성 향 아동의 성별 차이를 알아보기 위해 독립표본 $t$ 검증을 실시하였으며, 학년별 차이를 알아보기 위해 일원변량분석을 실시하였고, 사후검증으로 Scheffe 검증을 실시하였다.

둘째, 선별된 $\mathrm{ADHD}$ 성향 아동과 일반 아동 간 교사의 지지, 또래편견, 부모-교사 협력, 부모또래 관심 및 또래관계에서의 차이를 살펴보기 위해 독립표본 $t$ 검증을 실시하였다.

셋째, 초등학생의 $\mathrm{ADHD}$ 성향과 교사의 지지, 또래편견, 부모-교사 협력, 부모-또래 관심 및 또래관계 간의 관계를 살펴보기 위해 상관분석과 입력방식의 중다회귀분석을 실시하였다.

\section{IV. 연구 결과}

\section{1. 초등학생의 $\mathrm{ADHD}$ 성향 유병률}

초등학교 고학년 아동 1429 명의 교사용 K-ARS 척도 실시 결과, 17 점 이상인 아동이 319 명으 로, $22.32 \%$ 의 아동이 $\mathrm{ADHD}$ 성향을 나타냈다. 학년별로 살펴보면 6학년 435명 가운데 157 명 
(36.09\%)의 아동이 $\mathrm{ADHD}$ 성향 아동으로 선별되어 가장 많았고, 5학년은 453명 중에 86명 $(19.77 \%), 4$ 학년은 541 명 가운데 76 명(14.05\%)이 선별되었다. 선별된 $\mathrm{ADHD}$ 성향 아동의 성별을 살펴보면, 남학생은 전체 733 명 중에서 231명(31.51\%)이, 여학생은 전체 696명 중에서 88명 $(12.64 \%)$ 이 선별되어, 약 3:1의 비율로 남학생이 더 많은 것으로 나타났다. 학년별 대상자 수의 성별 차이를 살펴보면, 남학생은 6학년이 99명(42.86\%)으로 가장 많았고, 여학생 중에서도 6학년 이 58 명 $(65.91 \%)$ 으로 가장 많았다.

선별된 $\mathrm{ADHD}$ 성향 아동의 학년별 및 성별 분포율은 <표 $1>$ 에 제시되어 있다.

<표 1> ADHD 성향에 대한 학년별 및 성별 분포 비율

\begin{tabular}{cccc}
\hline \multirow{2}{*}{ 구분 } & \multicolumn{3}{c}{ ADHD 성향 아동 } \\
\cline { 2 - 4 } & 남자(\%) & 여자 $(\%)$ & 전체 $(\%)$ \\
\hline 4학년 & $57(17.9 \%)$ & $19(6.0 \%)$ & $76(23.8 \%)$ \\
\hline 5학년 & $75(23.5 \%)$ & $11(3.4 \%)$ & $86(27.0 \%)$ \\
\hline 6학년 & $99(31.0 \%)$ & $58(18.2 \%)$ & $157(49.2 \%)$ \\
\hline 전체 & $231(72.4 \%)$ & $88(27.6 \%)$ & $319(100 \%)$ \\
\hline
\end{tabular}

1) $\mathrm{ADHD}$ 성향의 성별 차이

본 연구에서 선별된 $\mathrm{ADHD}$ 성향 아동이 성별에 따라 $\mathrm{ADHD}$ 평가 척도에서 유의한 차이를 보이는지 살펴보기 위해 독립표본 $t$ 검증을 실시하였고, 그 결과는 <표 $2>$ 와 같다.

<표 2> ADHD 성향의 성별 차이

\begin{tabular}{cccc}
\hline \multirow{2}{*}{ 구분 } & 남자 $(N=231)$ & 여자 $(N=88)$ & \multirow{2}{*}{$t$} \\
\cline { 2 - 3 } & $\mathrm{M}(\mathrm{SD})$ & $\mathrm{M}(\mathrm{SD})$ & $3.27^{* *}$ \\
\hline 주의력결핍 & $14.24(4.55)$ & $12.49(4.18)$ & $3.78^{* *}$ \\
\hline 과잉행동 · 충동 & $13.06(5.12)$ & $10.74(4.30)$ & $3.99^{* * *}$ \\
\hline $\mathrm{ADHD}$ 합 & $27.30(8.46)$ & $23.23(7.29)$ & \\
\hline
\end{tabular}

${ }^{* * *} p<.001,{ }^{* *} p<.01$

표 2에 의하면, 교사가 보고한 아동의 $\mathrm{ADHD}$ 성향은 성별에 따라 유의미한 차이를 보였다. 주의력결핍 $(t=3.27, p<.01)$, 과잉행동충동( $t=3.78, p<.01), \mathrm{ADHD}$ 합 $(t=3.99, p<.001)$ 모두에서 남 아의 점수가 여아의 점수보다 더 높은 것으로 나타났다. 


\section{2) $\mathrm{ADHD}$ 성향의 학년별 차이}

$\mathrm{ADHD}$ 성향 아동이 학년에 따라 $\mathrm{ADHD}$ 성향 점수에서 차이를 나타내는지 살펴보기 위해 일원변량분석을 실시하였고, Scheffe 검증을 통해 하위집단 간 차이를 분석하였다. 그 결과와 각 학년별 주의력결핍, 과잉행동·충동, $\mathrm{ADHD}$ 합 점수의 평균과 표준편차를 <표 $3>$ 과 <표 $4>$ 에 제시하였다.

<표 $4>$ 를 살펴보면, 교사가 보고한 아동의 $\mathrm{ADHD}$ 성향은 주의력결핍 $(F=5.66, p<.01)$ 과 $\mathrm{ADHD}$ 합 $(F=3.59, p<.05)$ 에서 차이가 나타났으나, 과잉행동·충동 $(F=1.12, p>05)$ 의 경우는 학년 별 차이가 유의하지 않았다. 구체적으로 어느 학년에서 유의한 차이가 있는지 살펴보기 위해 Scheffe 검증을 실시한 결과, 4 학년 아동의 주의력결핍 $(M=16.38, S D=14.43)$ 과 $\mathrm{ADHD}$ 합 $(M=30.69, S D=10.41)$ 점수가 6 학년 아동의 주의력결핍 $(M=13.49, S D=4.75)$ 과 $\mathrm{ADHD}$ 합 $(M=26.06, S D=9.09)$ 점수에 비해 더 높은 것으로 나타났다.

<표 3> ADHD 성향의 학년별 평균과 표준편차

\begin{tabular}{ccccc}
\hline \multirow{2}{*}{ 구분 } & 4학년 $(N=76)$ & 5학년 $(N=86)$ & 6학년 $(N=157)$ & 전체 $(N=319)$ \\
\cline { 2 - 5 } & $M(\mathrm{SD})$ & $M(\mathrm{SD})$ & $M(\mathrm{SD})$ & $M(\mathrm{SD})$ \\
\hline 주의력결핍 & $14.97(4.84)$ & $14.14(5.02)$ & $12.96(3.88)$ & $13.76(4.51)$ \\
\hline 과잉행동 · 충동 & $12.84(5.94)$ & $12.83(5.60)$ & $11.99(4.10)$ & $12.41(5.01)$ \\
\hline $\mathrm{ADHD}$ 합 & $27.82(9.44)$ & $26.97(9.20)$ & $24.96(7.05)$ & $26.18(8.34)$ \\
\hline
\end{tabular}

<표 4> ADHD 성향의 학년별 차이

\begin{tabular}{|c|c|c|c|c|c|c|}
\hline 구분 & & 제곱합 & $d f$ & 평균제곱 & $F$ & Scheffe \\
\hline \multirow{3}{*}{ 주의력결핍 } & 집단 & 224.370 & 2 & 112.185 & \multirow{3}{*}{$5.66^{* *}$} & \multirow{3}{*}{$4>6$} \\
\hline & 오차 & 6244.044 & 316 & 19.760 & & \\
\hline & 합계 & 6468.414 & 318 & & & \\
\hline \multirow{3}{*}{ 과잉행동 - 충동 } & 집단 & 56.229 & 2 & 28.114 & \multirow{3}{*}{1.12} & \\
\hline & 오차 & 7931.483 & 316 & 25.100 & & \\
\hline & 합계 & 7987.712 & 318 & & & \\
\hline \multirow{3}{*}{$\mathrm{ADHD}$ 합 } & 집단 & 491.811 & 2 & 245.905 & \multirow{3}{*}{$3.59^{*}$} & \multirow{3}{*}{$4>6$} \\
\hline & 오차 & 21639.004 & 316 & 68.478 & & \\
\hline & 합계 & 22130.815 & 318 & & & \\
\hline
\end{tabular}




\section{2. $\mathrm{ADHD}$ 성향 아동과 일반 아동 간의 환경적 변인들 및 또래관계의 차이}

$\mathrm{ADHD}$ 성향 아동과 일반 아동 간 환경적 변인들 및 또래관계에서 차이가 있는지 살펴보기 위해, $\mathrm{ADHD}$ 성향 아동과 일반 아동(non-ADHD) 집단으로 나누어 차이검증을 실시하였다. 본 연구에서 환경적 변인들은 선행연구에 의해 교사의 지지, 또래편견, 부모-학교 협력과 부모-또래 관심으로 선정하였다. 일반 아동(non-ADHD) 집단은 전체 연구대상인 1429 명 가운데, 본 연구 에서 $\mathrm{ADHD}$ 성향 아동으로 선별된 319 명을 제외한 1110 명으로 구분하였고, 그 결과는 <표 5>에 제시되어 있다.

<표 5>를 살펴보면, $\mathrm{ADHD}$ 성향 아동과 일반 아동(non-ADHD) 집단 간 교사의 지지 $(t=-4.44$, $p<.001)$, 또래편견( $t=6.93, p<.001)$, 부모-학교 협력( $t=-2.86, p<.01)$, 부모-또래 관심( $t=-6.12$, $p<.001)$, 또래관계기술 $(t=-5.73, p<.001)$ 에서 유의한 차이가 나타났다. 즉 $\mathrm{ADHD}$ 성향 아동과 일 반 아동(non-ADHD) 간의 모든 변인들에서 유의한 차이가 나타났다.

<표 5> ADHD 성향 아동과 일반 아동 간 환경적 변인들 및 또래관계의 차이

\begin{tabular}{cccc}
\hline \multirow{2}{*}{ 구분 } & ADHD 성향 아동 $(N=319)$ & 일반 아동 $(N=1110)$ & \multirow{2}{*}{$t$} \\
\cline { 2 - 4 } & $M(\mathrm{SD})$ & $M(\mathrm{SD})$ & $-4.44^{* * *}$ \\
\hline 교사의 지지 & $21.23(6.21)$ & $23.10(6.09)$ & $6.93^{* * *}$ \\
\hline 또래편견 & $.85(1.25)$ & $.37(.87)$ & $-2.86^{* *}$ \\
\hline 부모-학교 협력 & $5.88(2.79)$ & $6.42(2.78)$ & $-6.12^{* * *}$ \\
\hline 부모-또래 관심 & $12.96(2.94)$ & $14.16(2.78)$ & $-5.73^{* * *}$ \\
\hline 또래관계기술 & $39.39(9.41)$ & $42.93(8.41)$ &
\end{tabular}

${ }^{* * *} p<.001,{ }^{* *} p<.01$

\section{3. 초등학생의 $\mathrm{ADHD}$ 성향과 환경적 변인들 및 또래관계 간의 관계}

아동의 $\mathrm{ADHD}$ 성향과 환경적 변인들인 교사의 지지, 또래편견, 부모-학교 협력, 부모-또래 관 심 및 또래관계 간의 관계를 알아보기 위해 상관분석을 실시하였다. 상관계수는 $\mathrm{ADHD}$ 성향 아동과 일반 아동(non-ADHD) 집단, 그리고 $\mathrm{ADHD}$ 성향 아동과 일반 아동 모두를 포함하는 전체 아동 집단으로 나누었고, 그 결과는 <표 6>에 제시하였다.

<표 6>을 살펴보면, $\mathrm{ADHD}$ 성향은 또래편견과는 정적상관을, 교사의 지지, 부모-교사 협력, 부모-또래관심 및 또래관계기술과는 부적상관을 나타냈다. 교사의 지지는 또래편견과는 부적상 관을, 부모-학교 협력, 부모-또래관심, 또래관계기술과는 정적상관을 나타냈다. 또래편견은 부모학교 협력, 부모-또래 관심 및 또래관계기술과 부적상관을, 부모-학교 협력은 부모-또래 관심과 또래관계와 정적상관을, 부모-또래 관심은 또래관계기술과 정적상관을 나타냈다. 그러나 
$\mathrm{ADHD}$ 성향 아동의 경우, $\mathrm{ADHD}$ 성향은 교사의 지지 및 부모-학교 협력과 유의한 상관을 보이 지 않았다. $\mathrm{ADHD}$ 성향 아동, 일반 아동 및 전체 아동 집단 모두에서 부모-또래 관심과 또래관 계기술 간 다소 높은 상관이 있었으며, 교사의 지지와 또래관계기술, 부모-학교 협력과 부모-또 래 관심 간에도 높은 상관이 나타났다.

<표 6> ADHD 성향과 환경적 변인들 및 또래관계 간의 상관관계

\begin{tabular}{|c|c|c|c|c|c|c|c|}
\hline 구분 & & 1 & 2 & 3 & 4 & 5 & 6 \\
\hline \multirow{6}{*}{$\begin{array}{c}\mathrm{ADHD} \\
\text { 성향 아동 } \\
(N=319)\end{array}$} & 1. $\mathrm{ADHD}$ 성향 & - & -.08 & $.27^{* * *}$ & .01 & $-.13^{*}$ & $-.14^{*}$ \\
\hline & 2. 교사의 지지 & & - & $-.18^{* *}$ & $.23^{* * *}$ & $.25^{* * *}$ & $.41^{* * *}$ \\
\hline & 3. 또래편견 & & & - & -.11 & $-.24^{* * *}$ & $-.32^{* * *}$ \\
\hline & 4. 부모-학교 협력 & & & & - & $.40^{* * *}$ & $.36^{* * *}$ \\
\hline & 5. 부모-또래 관심 & & & & & - & $.51^{* * *}$ \\
\hline & 6. 또래관계기술 & & & & & & - \\
\hline \multirow{6}{*}{$\begin{array}{l}\text { 일반 아동 } \\
(N=1100)\end{array}$} & 1. $\mathrm{ADHD}$ 성향 & - & $-.16^{* * *}$ & $.24^{* * *}$ & $-.11^{* *}$ & $-.14^{* * *}$ & $-.22^{* * *}$ \\
\hline & 2. 교사의 지지 & & - & $-.16^{* * *}$ & $.30^{* * *}$ & $.35^{* * *}$ & $.42^{* * * *}$ \\
\hline & 3. 또래편견 & & & - & -.08 & $-.20^{* * *}$ & $-.22^{* * *}$ \\
\hline & 4. 부모-학교 협력 & & & & - & $.40^{* * * *}$ & $.33^{* * *}$ \\
\hline & 5. 부모-또래 관심 & & & & & - & $.47^{* * *}$ \\
\hline & 6. 또래관계기술 & & & & & & - \\
\hline \multirow{6}{*}{$\begin{array}{l}\text { 전체 아동 } \\
(N=1429)\end{array}$} & 1. $\mathrm{ADHD}$ 성향 & - & $-.18^{* * *}$ & $.31^{* * *}$ & $-.10^{* *}$ & $-.23^{* * *}$ & $-.24^{* * *}$ \\
\hline & 2. 교사의 지지 & & - & $-.19^{* * *}$ & $.28^{* * *}$ & $.34^{* * *}$ & $.43^{* * *}$ \\
\hline & 3. 또래편견 & & & - & $-.10^{* *}$ & $-.25^{* * *}$ & $-.29^{* * *}$ \\
\hline & 4. 부모-학교 협력 & & & & - & $.41^{* * *}$ & $.35^{* * *}$ \\
\hline & 5. 부모-또래 관심 & & & & & - & $.50^{* * *}$ \\
\hline & 6. 또래관계기술 & & & & & & - \\
\hline
\end{tabular}

${ }^{* * *} p<.001,{ }^{* *} p<.01,{ }^{*} p<.05$

$\mathrm{ADHD}$ 성향과 환경적 변인들인 교사의 지지, 또래편견, 부모-학교 협력, 부모-또래 관심이 또 래관계에 미치는 영향력을 살펴보기 위해 또래관계기술을 준거변인으로 투입하고, $\mathrm{ADHD}$ 성향 및 환경적 변인들을 예측변인으로 하여 입력방법의 중다회귀분석을 실시하였다. 중다회귀분석 결과는 $\mathrm{ADHD}$ 성향 아동과 일반 아동, 그리고 전체 아동 집단으로 나누어서 제시하였다. 종속변 인에 대한 예측변인 전체의 설명력 $\left(R^{2}\right)$ 과 $F$ 값, 표준화계수 $(\beta)$ 와 $t$ 값은 <표 $7>$ 에 제시되어 있다.

$\mathrm{ADHD}$ 성향 아동의 경우, $\mathrm{ADHD}$ 성향을 제외한 모든 환경적 변인들이 또래관계기술에 영향 을 주는 것으로 나타났으며, 전체 변량의 $38 \%$ 를 설명하였다 $\left(R^{2}=.38, F=37.16, p<.001\right)$. 즉 교사의 지지와 부모-학교 협력, 부모-또래 관심이 클수록 또한 또래편견이 적을수록 또래관계기술이 높 을 경향이 크다는 것을 알 수 있다. 예측변인의 상대적인 기여도를 살펴보면, 부모-또래 관심 $(\beta$ 
=.35)의 기여도가 가장 높고, 부모-학교 협력 $(\beta=.13)$ 이 가장 낮았다.

일반 아동의 경우, $\mathrm{ADHD}$ 성향 및 모든 환경적 변인들이 또래관계기술에 영향을 주는 것으로 나타났으며, 전체 변량의 $33 \%$ 를 설명하였다 $\left(R^{2}=.33, F=66.78, p<.001\right)$. 즉 교사의 지지와 부모-학 교 협력, 부모-또래 관심이 클수록 또한 $\mathrm{ADHD}$ 성향과 또래편견이 적을수록 또래관계기술이 높 을 경향이 크다는 것을 알 수 있다. 예측변인의 상대적인 기여도를 살펴보면, 부모-또래 관심 $\beta$ $=.31)$ 의 기여도가 가장 높고, 또래편견 $(\beta=-.08)$ 이 가장 낮았다.

전체 아동의 경우, $\mathrm{ADHD}$ 성향 및 모든 환경적 변인들이 또래관계기술에 영향을 주는 것으로 나타났으며, 전체 변량의 $37 \%$ 를 설명하였다 $\left(R^{2}=.37, F=113.56, p<.001\right)$. 즉 교사의 지지와 부모학교 협력, 부모-또래 관심이 클수록 그리고 $\mathrm{ADHD}$ 성향과 또래편견이 적을수록 또래관계기술 이 높을 경향이 크다는 것을 알 수 있다. 예측변인의 상대적인 기여도를 살펴보면, 부모-또래 관심 $(\beta=.32)$ 의 기여도가 가장 높고, $\mathrm{ADHD}$ 성향 $(\beta=-.07)$ 이 가장 낮았다.

<표 7> 또래관계에 대한 $\mathrm{ADHD}$ 성향 및 환경적 변인들의 중다회귀분석

\begin{tabular}{|c|c|c|c|c|c|c|}
\hline 준거변인 & 집단구분 & 예측변인 & $\mathrm{R}^{2}$ & $F$ & $\bar{\beta}$ & $t$ \\
\hline \multirow{15}{*}{$\begin{array}{l}\text { 또 } \\
\text { 래 } \\
\text { 관 } \\
\text { 계 } \\
\text { 기 } \\
\text { 술 }\end{array}$} & \multirow{5}{*}{$\begin{array}{c}\mathrm{ADHD} \text { 성향 아동 } \\
\quad(N=319)\end{array}$} & $\mathrm{ADHD}$ 성향 & \multirow{5}{*}{.38} & \multirow{5}{*}{$37.16^{* * *}$} & -.02 & -.33 \\
\hline & & 교사의 지지 & & & .25 & $5.33^{* * *}$ \\
\hline & & 또래편견 & & & -.17 & $-3.46^{* *}$ \\
\hline & & 부모-학교 협력 & & & .13 & $2.65^{* *}$ \\
\hline & & 부모-또래 관심 & & & .35 & $6.81^{* * *}$ \\
\hline & \multirow{5}{*}{$\begin{array}{l}\text { 일반 아동 } \\
(N=1100)\end{array}$} & $\mathrm{ADHD}$ 성향 & \multirow{5}{*}{.33} & \multirow{5}{*}{$66.78^{* * *}$} & -.10 & $-3.00^{* *}$ \\
\hline & & 교사의 지지 & & & .25 & $7.15^{* * *}$ \\
\hline & & 또래편견 & & & -.08 & $-2.43^{*}$ \\
\hline & & 부모-학교 협력 & & & .13 & $3.64^{* * *}$ \\
\hline & & 부모-또래 관심 & & & .31 & $8.53^{* * *}$ \\
\hline & \multirow{5}{*}{$\begin{array}{l}\text { 전체 아동 } \\
(N=1429)\end{array}$} & $\mathrm{ADHD}$ 성향 & \multirow{5}{*}{.37} & \multirow{5}{*}{$113.56^{* * *}$} & -.07 & $-2.68^{* * *}$ \\
\hline & & 교사의 지지 & & & .25 & $8.99^{* * *}$ \\
\hline & & 또래편견 & & & -.12 & $-4.45^{* * * *}$ \\
\hline & & 부모-학교 협력 & & & .13 & $4.62^{* * * *}$ \\
\hline & & 부모-또래 관심 & & & .32 & $10.90^{* * * *}$ \\
\hline
\end{tabular}

\footnotetext{
${ }^{* * * *} p<.001,{ }^{* *} p<.01,{ }^{*} p<.05$
} 


\section{$\mathrm{V}$. 논의 및 결론}

본 연구에서는 초등학교 $4,5,6$ 학년 아동의 교사보고 자료에 기초하여 $\mathrm{ADHD}$ 성향 유병률을 확인하고, 초등학생의 $\mathrm{ADHD}$ 성향과 환경적 변인들인 교사의 지지, 또래편견, 부모-학교 협력, 부모-또래 관심 및 또래관계 간의 관련성을 살펴보았다. 본 연구에서 얻어진 결과를 종합하여 논의하면 다음과 같다.

첫째, 교사보고 결과에 기초하여, 초등학교 4, 5, 6학년 아동의 $\mathrm{ADHD}$ 성향 유병률은 $22.32 \%$ 로 나타났다. 이는 $\mathrm{ADHD}$ 성향 유병률에 관한 국내 선행연구결과와 비교했을 때 다소 차이가 있다. 아동의 자기보고 자료에 기초한 표경식 등(2001)의 $6.1 \%$ 나 이동훈(2009)의 $9.6 \%$, 부모보고 에 근거한 Cho 등(2009)의 9.0\%에 비해 매우 높은 수치이다. 경기도와 경기도교육청이 2010년 보고한 $11.4 \%$ (서울신문, 2010.08.26)에 비해서도 거의 두 배에 가까운 높은 수치라 할 수 있다. 또한 본 연구결과, 학년이 증가할수록 $\mathrm{ADHD}$ 성향을 보이는 아동의 수가 증가하였다. 4,5 학년 에 비해 6학년 아동의 수가 가장 많은 것으로 나타났다. 본 연구에서 남학생과 여학생의 비율은 약 3:1로 나타났다. 이는 $\mathrm{ADHD}$ 성향 유병률이 남아에게서 더 높게 나타나는 것으로 보고하는 연구들(이동훈, 2009; 표경식 등, 2001; Cho et al., 2009)과 그 맥을 같이 한다.

본 연구에서의 유병률 결과는 선행연구들과의 유병률 조사 방법상의 차이, 즉 표집대상의 학 년이나 지역, 평가자 등의 차이에서 기인했을 수 있어 선행연구들의 결과와 직접적으로 비교하 는 데는 무리가 있다. 또한 본 연구에서 나타난 학년별 아동의 수의 차이가 본 연구에 참가한 대상에 한한 것인지 아니면 실제적인 차이를 반영하는 것인지에 대해선 지속적인 연구를 통해 확인해나갈 필요가 있다. 그러나 교사보고에 의해 측정된 본 연구의 유병률 수치가 자기보고나 부모보고에 의해 측정된 수치에 비해 상대적으로 높은 것에 대해서는 주목할 필요가 있을 것이 다. 교사에 의한 보고는 해당 아동에 대한 교사의 주관적인 지각을 담고 있기 때문에 개인마다 차이가 있을 수 있다. 그러나 교사는 자신이 맡은 학급 속에서 아동들을 다 알고 있고, 아동을 관찰하고 아동과 상호작용 할 수 있으며, 발달 수준이 동일한 아동들 간의 비교가 가능하다. 또 한 주의력을 요하는 과제에 있어서도 아동의 반응을 누구보다 더 잘 관찰할 수 있다(송수미, 김 재환, 2002). 다시 말해, 교사보고에 의해 측정된 유병률이 부모보고나 아동의 자기보고에 의해 측정된 유병률에 비해 높다는 것은 그만큼 현재 학교 현장에서 많은 교사들이 $\mathrm{ADHD}$ 성향의 아동들로 인해 어려움을 경험하고 있음을 나타낸다고 볼 수 있을 것이다. $\mathrm{ADHD}$ 성향 아동은 임상장면에서 $\mathrm{ADHD}$ 로 진단받은 것이 아니기 때문에 대부분 일반 학급에 통합되어 담임교사 한 명의 지도하에 교육을 받고 있는 경우가 많다. 교사들은 이들을 치료의 대상으로 인식하기보 다 '말 안 듣는 아이’나 '문제아’ 등으로 간주해버리기 쉽고, 이들로 인해 수업 운영에서도 많은 스트레스를 경험할 수 있다(이정은, 김춘경, 2009; 최연숙, 2014). 아동들 또한 주위로부터 부정적 
인 피드백을 계속 듣게 되면 자신감을 상실하여 정서적인 어려움을 겪거나 반대로 반항심이 생 겨 문제 행동이 증가할 수 있어, 교사나 아동 모두의 학교생활에 어려움은 더욱 가중될 수 있다. 따라서 학교 현장에서의 $\mathrm{ADHD}$ 성향 아동에 대한 올바른 이해와 인식을 위한 방안 마련이 시급 하다고 볼 수 있다.

교사가 지각한 아동의 $\mathrm{ADHD}$ 성향의 점수는 성별에 따라 유의한 차이가 나타났다. 남학생들 이 여학생에 비해 주의력결핍, 과잉행동충동, $\mathrm{ADHD}$ 합에서 모두 높은 점수를 나타냈다. 이러 한 연구결과는 주의력결핍과 과잉행동충동에 성차가 존재하며 남학생이 여학생에 비해 더 높은 점수를 보인다는 선행연구결과(이동훈, 2009; 표경식 외, 2001; Cho et al., 2009)와 일치한다. $\mathrm{ADHD}$ 성향을 나타낸 남학생과 여학생의 점수 차이에 근거해 볼 때 $\mathrm{ADHD}$ 성향 여학생이 $\mathrm{ADHD}$ 성향 남학생에 비해 낮은 관심을 받을 가능성이 높다고 볼 수 있다. 신체적인 행동을 자주 보이는 남학생과는 달리 주의력결핍을 보이는 여학생이라면 대부분 대수롭지 않게 넘길 가능성도 크다. $\mathrm{ADHD}$ 아동을 대상으로 한 선행연구에 의하면 또래거부를 경험한 $\mathrm{ADHD}$ 여학 생은 같은 수준으로 또래거부를 경험한 $\mathrm{ADHD}$ 남학생보다 더욱 부정적인 예후를 나타낼 수 있 고(Mikami \& Hinshaw, 2003), 우울이나 불안과 같은 내현화 증상에 있어서는 여학생이 남학생 에 비해 더 많은 손상을 보이는 것(Rucklidge \& Tannock, 2001)으로 보고되고 있다. 이러한 결과 에 비추어 봤을 때 $\mathrm{ADHD}$ 성향을 보이는 여학생에게 주의를 기울여야 함과 동시에, 이러한 성 별 차이의 원인을 살펴보는 연구가 지속되어야 할 것이다.

교사가 지각한 아동의 $\mathrm{ADHD}$ 성향 점수는 학년에 따라 유의한 차이가 나타났다. 4 학년과 5학 년, 5학년과 6학년 간 점수에는 차이가 없었지만, 4 학년과 6학년 간에는 주의력결핍과 $\mathrm{ADHD}$ 합의 점수에서 차이가 나타났다. 이는 동일한 K-ARS 평가 척도를 활용하였으나 초등학생 간에 는 연령에 따른 점수 차이가 나타나지 않은 연구결과(김영신 외, 2003)와 상반된 결과로서, $\mathrm{ADHD}$ 아동의 연령이 증가함에 따라 주의력결핍은 남아있지만 과잉행동이나 충동적 행동 특성 은 감소한다는 주장(Cantwell, 1999; DuPaul et al., 1997; Jeong et al., 2001)과도 상반된 결과로 볼 수 있다. 이러한 결과 또한 본 연구에 참가한 대상에 한한 것인지 아니면 실제적인 차이를 반영하는 것인지에 대해선 향후 초등학교 저학년이나 청소년으로 대상을 확대함과 동시에 여러 평가자를 통해 확인하는 연구가 지속될 필요가 있을 것이다.

본 연구에서의 $4,5,6$ 학년 아동들 중에서는 4 학년 아동의 점수가 가장 높은 반면, 6 학년 아동 의 수가 가장 많이 나타났다. 즉, 4 학년의 경우 선별된 $\mathrm{ADHD}$ 성향 아동의 수는 가장 적은 반면 점수는 가장 높았고, 6학년의 경우는 선별된 $\mathrm{ADHD}$ 성향 아동의 수는 가장 많은 반면 점수는 가장 낮았다. 본 연구의 결과만으로 이와 같은 점을 논하기엔 한계가 있지만, 이러한 결과는 $\mathrm{ADHD}$ 성향 아동의 조기 발견의 중요성을 다시 한 번 확인시켜주는 것으로 볼 수 있을 것이다. $\mathrm{ADHD}$ 로 진단받을 수준은 아니지만 이와 유사한 증상을 보이는 $\mathrm{ADHD}$ 성향 아동에게 적절한 
개입이나 치료가 시행되지 않는다면 $\mathrm{ADHD}$ 로 진단되거나 또 다른 형태의 이차적 문제로 이어 질 가능성 또한 매우 높으며(Cho et al., 2009), 이미 여러 선행연구들을 통해 ADHD 성향으로 인해 여러 심리사회적 부적응을 경험하고 있음이 보고되고 있다(김홍석 외, 2013; 이동훈, 2009, 2011; 최진오, 2012; Lewinsohn et al., 2004; Yoo et al., 2004). ADHD 성향은 학교라는 구조화된 환경에서 가장 두드러지고, 이러한 행동 특성은 우리나라와 같은 다인수 학급에서 교사나 다른 아동의 학교생활적응에 직접적인 영향력을 미칠 수 있어, $\mathrm{ADHD}$ 성향 아동의 증가는 커다란 교육적 현안이라 할 수 있을 것이다. 따라서 $\mathrm{ADHD}$ 성향 아동이 증가하는 데 있어서의 원인을 다각도로 살펴보아 이를 조기에 발견하여 개입하는 노력이 반드시 이루어져야 할 것이다.

둘째, $\mathrm{ADHD}$ 성향 아동과 일반 아동 간 환경적 변인들과 또래관계 간에 차이가 있는지 살펴 본 결과, 모든 변인들에서 유의한 차이가 나타났다. 즉, 본 연구에서 $\mathrm{ADHD}$ 성향 아동의 또래관 계에 영향을 미칠 것으로 선정한 환경적 변인들인, 교사의 지지, 또래편견, 부모-학교 협력 및 부모-또래 관심과 또래관계에서 $\mathrm{ADHD}$ 성향 아동과 일반 아동 간에 차이가 나타났다. $\mathrm{ADHD}$ 성향 아동은 일반 아동에 비해 교사로부터 지지를 덜 받는 것으로 지각하고 있었으며, 자신들의 부모는 일반 아동의 부모에 비해 학교와 덜 협력하고 친구들에 대해 관심이 더 적은 것으로 보 고하였다. 또한 이들은 일반 아동에 비해 또래로부터 더 많은 편견을 받고 있다고 지각하였다. 무엇보다도 $\mathrm{ADHD}$ 성향 아동은 일반 아동에 비해 또래관계기술이 떨어지는 것으로 나타났다. 이는 $\mathrm{ADHD}$ 성향 아동이 일반 아동에 비해 또래와의 관계 형성에서 어려움을 나타내고(이동훈, 2011), ADHD 성향이 높을수록 더 많은 또래거부를 경험한다(Diamantopoulou et al., 2005)는 선행연구들을 지지하는 것으로, $\mathrm{ADHD}$ 성향 아동이 일반 아동에 비해 또래관계에서 더 많은 어려움을 경험하고 있음을 제시한다. 이로써 $\mathrm{ADHD}$ 로 진단받진 않더라도 이와 유사한 증상을 보이는 $\mathrm{ADHD}$ 성향 아동 또한 $\mathrm{ADHD}$ 아동과 동일하게 또래관계에서 어려움을 경험하고 있음 을 알 수 있다.

이와 더불어 환경적 변인들이 $\mathrm{ADHD}$ 성향 아동의 또래관계에 미치는 영향력을 살펴본 결과, 교사의 지지, 또래편견, 부모-학교 협력 및 부모-또래 관심은 $\mathrm{ADHD}$ 성향 아동의 또래관계에 영향을 미치는 것으로 나타났다. 이는 교사와 학생 간의 긍정적인 관계가 학생의 사회적 역량을 높여주고, 학생과 학생 간 상호작용에 변화를 가져왔다는 연구결과들(Mikami, Lerner et al., 2010; Mikami et al., 2011)을 지지한다. 또래로부터의 편견이 ADHD 아동의 또래거부를 지속시 킬 수 있음을 보고한 연구결과(Hoza et al., 2005)와도 그 맥을 같이 한다. 또한 부모-학교 협력이 $\mathrm{ADHD}$ 아동의 사회적 유능성에도 영향을 미치는 것으로 보고한 연구결과(이미아, 2008)와 부모 가 또래 간 관계가 좋을수록 자녀가 또래로부터 좋아하는 친구로 지명 받는 횟수도 증가하는 것으로 나타난 연구결과(도금혜, 최보가, 2007)와도 그 맥을 같이 한다. 즉, $\mathrm{ADHD}$ 성향 아동의 또래관계 어려움은 환경적 맥락에서 이해될 필요가 있음을 의미한다고 볼 수 있다. 
$\mathrm{ADHD}$ 성향 아동을 가르치고 지도함에 있어 교사들은 많은 스트레스를 경험하고 있다(이정 은, 김춘경, 2009; 최연숙, 2014). 이로 인해 $\mathrm{ADHD}$ 성향 아동은 일반 아동에 비해 교사로부터 긍정적인 지지를 받기 어려운데, 이는 $\mathrm{ADHD}$ 성향 아동의 또래관계에 영향을 미치는 것으로 나타났다. 따라서 $\mathrm{ADHD}$ 성향 아동의 또래관계 증진을 위해서 이들을 향한 교사의 긍정적 지지 를 높여주어야 할 것이다. 교사가 $\mathrm{ADHD}$ 성향 아동에 대해 긍정적 태도를 갖기 위해서는 $\mathrm{ADHD}$ 성향에 대한 지식수준이 높아야 한다는 보고가 있다(정종성, 최진오, 2010). 이에 교사가 $\mathrm{ADHD}$ 성향 아동에 대한 바른 인식과 지식을 가짐으로써 아동과의 긍정적인 상호작용을 높일 수 있는 방향으로의 다양한 지원이 제공될 필요가 있을 것이다.

$\mathrm{ADHD}$ 성향 아동은 또래들에게 부정적인 인상을 주기 쉽다. 한 아동에 대해 또래들이 부정적 인 편견을 갖게 되면, 그 편견은 그 집단에 빨리 퍼져 나가고, 이로 인해 또래들로부터 더욱 더 부정적인 취급을 당하게 되어 더 고통 받는 악순환이 계속될 수 있다(McQuade \& Hoza, 2008). 이러한 점에서 $\mathrm{ADHD}$ 성향 아동에 대한 또래의 편견은 일반 아동에 비해 더 심각하다고 볼 수 있는데, 이러한 또래의 부정적인 편견은 $\mathrm{ADHD}$ 성향 아동의 또래거부를 지속시키는 결과를 가 져올 수 있다. 또래가 $\mathrm{ADHD}$ 성향 아동에 대해 가진 생각이 바뀌지 않는다면, $\mathrm{ADHD}$ 성향 아동 이 부적절한 행동을 더 이상 하지 않는다고 해도 또래거부는 계속될 수 있기 때문이다(Hoza et al., 2005). 따라서 또래들을 비롯하여 학교 내 구성원들이 서로에 대해 부정적인 시각을 갖고 있지 않는지 확인하여 이를 바꿔주거나, 상호 존중하는 관계의 중요성을 강조하는 등의 노력이 필요할 것으로 보인다.

$\mathrm{ADHD}$ 성향 아동의 행동적 특성상, 부모의 학교 활동 참여는 필수적이다(황순영, 2011). 그러 나 본 연구에서 $\mathrm{ADHD}$ 성향 아동이 보고한 부모의 학교활동 참여는 일반 아동이 보고한 부모의 학교활동 참여에 비해 더 적은 것으로 나타났다. 선행연구에 의하면, 교사는 $\mathrm{ADHD}$ 자녀를 둔 부모가 자녀의 증상을 인정하려 하지 않아 부모와 상담이 어렵고, 자녀의 증상을 인정한다고 해 도 교육에 있어서 무관심한 태도를 보이는 경우가 많아 부모와의 협력에 어려움을 호소하고 있 다(서석진, 강미라, 양경애, 2013). 부모는 자녀가 ADHD라는 사실을 교사에게 알리고 도움을 요청했지만 교사로부터 낙인을 경험했거나(오원옥, 박은숙, 2007), 혹 자녀가 교사로부터 장애아 라는 낙인을 받을까 염려되어 $\mathrm{ADHD}$ 라고 알리는 것을 꺼려하는 경향도 보였다(김남형, 2009). 즉, 교사와 부모 사이의 불신으로 인해 부모-학교 협력이 어려울 수 있는데, 이러한 상호 협력은 이들의 또래관계에 영향을 미치게 되는 것이다. 따라서 $\mathrm{ADHD}$ 성향 아동의 부모와 교사는 학교 와 가정에서의 지속적인 상호작용을 통해 협력을 지속하고, 학교와 가정에서의 교육과 양육에서 의 일관성을 유지하는 방향으로 함께 치료 방안을 논의하는 등(Pfiffner et al., 2013)의 많은 노력 을 기울여야 할 것이다.

$\mathrm{ADHD}$ 성향 아동과 일반 아동 간 부모-또래 관심에서 차이가 나타났다. 이는 일반 아동에 
비해 $\mathrm{ADHD}$ 아동의 부모가 친구를 집으로 초대하는 횟수가 훨씬 적은 것으로 나타난 연구결과 (Mikami, Jack et al., 2010)를 지지한다. ADHD 아동을 둔 부모는 일반 아동을 둔 부모에 비해 따뜻한 말이나 행동보다 부정적인 말이나 신체적인 벌, 통제나 비난 등을 더 많이 사용하고(고명 정 외, 2011), 자녀의 반응에 덜 민감하여 상호작용의 빈도도 낮기 때문에(이성직, 2013), 자녀의 친구들에 대한 관심이 덜 할 수 있다. 따라서 $\mathrm{ADHD}$ 성향 아동의 부모는 아동이 또래관계에서 어려움을 경험한다는 점을 인식하여, 자녀에게 친구에 대해 물어보거나 친구를 집으로 초대하는 등의 관심을 기울일 필요가 있다. 특히 부모-또래 관심은 본 연구에서 선정한 환경적 변인들 중 에서 $\mathrm{ADHD}$ 성향 아동은 물론 일반 아동의 또래관계에서도 가장 높은 설명력을 나타냈다. 이와 관련해서 부모가 또래 친구에게 두는 관심이 아동의 또래관계에 미치는 기제에 관한 연구가 지 속된다면 이들의 관계를 증진시키기 위한 부모교육의 기초자료로 활용될 수 있을 것이다.

종합해보면, $\mathrm{ADHD}$ 성향 아동은 일반 아동에 비해 또래관계에서 어려움을 경험하고 있고, 이 러한 어려움은 이들이 속해 있는 환경적 맥락에서 이해되어질 필요가 있음을 확인하였다. 즉, 관계에서 발생하는 문제는 개인적인 특성에 의해 나타나기도 하지만, 환경과의 상호작용 속에서 도 발생할 수 있다는 것이다. 또한 환경들 간의 협력 관계 역시 이들의 또래관계 어려움에 영향 을 미치는 것으로 나타나, $\mathrm{ADHD}$ 성향 아동의 교육과 중재에 있어 부모와 학교의 상호 협력이 중요함을 알 수 있다. 개인의 발달은 개인을 둘러싸고 있는 환경을 떠나서 이해할 수 없기 때문 에(Bronfenbrenner, 1979), $\mathrm{ADHD}$ 성향 아동의 또래관계 증진을 위해 교사나 또래, 부모가 각자 가 겪는 어려움을 잘 대처하고, 이를 기반으로 서로가 협력하여 상호도움이 되는 방향으로의 개 입이 이루어진다면 보다 긍정적인 효과를 초래할 수 있을 것이다.

아울러 본 연구결과는 $\mathrm{ADHD}$ 성향 아동의 관계 문제를 예방하는 차원에서의 개입으로도 활 용될 수 있을 것이다. 예를 들어, 평소 이들을 향한 교사의 긍정적인 지원을 증가시키며, 또래를 비롯하여 학교 내 구성원들 간의 부정적인 시각을 변화시켜 주는 방향으로의 개입이 시행된다 면 $\mathrm{ADHD}$ 성향 아동이 관계에서 겪는 어려움을 사전에 미리 예방하는 효과를 기대할 수 있을 것이다(송연주, 이동훈, 2013). 본 연구를 통해 $\mathrm{ADHD}$ 성향 아동의 또래관계 어려움에 있어서의 환경의 중요성에 대한 인식을 시작으로, $\mathrm{ADHD}$ 성향 아동의 또래관계 증진을 위한 개입에 있어 교사, 또래, 부모 요인들이 적극적으로 활용되어지기를 기대해본다.

본 연구의 대상은 특정 지역 초등학교 고학년 아동만으로 이루어졌기 때문에 본 연구 결과를 일반화하는 데 어려움이 있다. 본 연구에서는 $\mathrm{ADHD}$ 성향을 측정한 평가 척도의 진단 기준인 17 점을 활용하여 $\mathrm{ADHD}$ 성향 아동을 선별하였다. 일반적으로 $\mathrm{ADHD}$ 로 진단하기 위해서는 전 문가가 부모보고나 교사보고, 아동의 자기보고, 직접적인 관찰, 보호자 인터뷰 등의 여러 절차를 거친 후 종합적으로 진단하지만, 본 연구에서는 교사보고 만을 활용하였기 때문에 17 점 이상의 모든 아동들을 $\mathrm{ADHD}$ 성향 아동으로 분류하였다. 향후 보다 정확한 임상적 진단 하에 지역을 
광범위하게 하고 표집대상도 전체 초등학생으로 확대한 연구가 시행된다면 $\mathrm{ADHD}$ 성향 유병률 에 대해 좀 더 자세한 정보를 확인할 수 있을 것이다. 본 연구에서는 $\mathrm{ADHD}$ 의 하위유형별 차이 를 살펴보지 못했다. $\mathrm{ADHD}$ 하위유형은 각기 다른 기제로 이들의 또래관계에 영향을 미칠 수 있기 때문에 향후 연구에서는 하위유형별 차이를 통해 또래관계 특성을 살펴보는 것도 의미가 있을 것이다. 또한 부모-또래 관심 척도의 신뢰도가 그리 높지 않고, 또래편견의 경우는 정적분 포가 강해 정상분포를 가정하기 어렵다는 점에서도 한계가 있다. 향후 부모-또래 관심과 또래편 견에 관한 보다 정확한 측정도구를 활용해 연구를 지속할 필요가 있을 것이다. 


\section{참고문헌}

고명정, 박은진, 이대환, 최영민, 김봉석(2011). 주의력결핍 과잉행동장애 아동에서 어머니의 대 상관계가 양육태도와 아동의 자아존중감에 미치는 영향. 소아청소년정신의 학, 22(4), 219-227.

김남형(2009). $\mathrm{ADHD}$ 아동의 학교적응을 위한 부모-교사의 협력적 관계형성 방안에 관한 연구. 임상사회사업연구, 6(3), 19-48.

김영신, 소유경, 노주선, 최낙경, 김세주, 고윤주(2003). 한국어판 부모 및 교사용 $\mathrm{ADHD}$ 평가 척도(K-ARS)의 규준 연구. 신경정신의학, 42(3), 352-359.

김은미(2012). 중학생의 학교생활적응에 영향을 미치는 생태학적 변인들의 구조분석. 석사학위

논문, 고려대학교 교육대학원.

김재원, 박기홍, 최민정(2004). 지역사회에서의 주의력결핍-과잉행동장애 선별기준에 대한 연구.

신경정신의 학, 43(2). 200-208.

김홍석, 송연주, 이동훈(2013). 초등학생의 자기보고된 $\mathrm{ADHD}$ 성향과 우울과의 관계에서 스트레

스의 조절효과. 한국심리학회지: 상담 및 심리치료, 25(2), 331-350.

도금혜(2007). 청소년의 인기도에 영향을 미치는 생태학적 변인. 박사학위논문, 경북대학교. 도금혜, 최보가(2007). 청소년의 또래집단이 지각한 인기도에 영향을 미치는 생태학적 변인. 한

국청소년연구, 18(1), 107-134.

박민정(2002). 청소년의 공격성에 영향을 미치는 생태학적 변인. 박사학위논문, 경북대학교. 서석진, 강미라, 양경애(2013). $\mathrm{ADHD}$ 아동에 대한 초등교사의 인식. 학습전략중재연구, 4(1),

79-102.

서울신문(2010, 8, 26). 경기 초등1년 1만 212명 'ADHD' 의심.

http:// www.seoul.co.kr/news/newsView.php?id=20100826016016

소유경, 노주선, 김영선, 고선규, 고윤주(2002). 한국어판 부모, 교사 $\mathrm{ADHD}$ 평가 척도의 신뢰도

와 타당도 연구. 신경정신의학, 41(2), 283-289.

송수미, 김재환(2002). $\mathrm{ADHD}$ 및 우울/불안장애 아동의 문제행동에 대한 부모-교사 간 평정 일 치도. 한국심리학회지: 임상, 21(4), 859-869.

송연주, 이동훈(2013). ADHD 아동의 또래관계 어려움에 대한 생태학적 관점에서의 이해. 열린 교육연구, 21(2), 307-330.

신동원, 이승민(2009). 주의력결핍 과잉행동장애 아동에서 집단따돌림 양상. 소아청소년정신의 학, 20(2), 90-96. 
양윤란, 오경자(2005). 또래관계기술 척도의 개발: 초등학교 4 학년-중학년 3학년 학생용. 한국심 리학회지: 임상, 24(4), 961-971.

오원옥, 박은숙(2007). 주의력결핍 과잉행동장애(ADHD) 아동 부모의 양육 경험: 정상에 다가가 기. 한국간호과학회, 37(1), 91-104.

이동훈(2009). 초등학생의 $\mathrm{ADHD}$ 증상 유병률 및 우울, 불안, 스트레스, 학교부적응과의 관계. 상담학연구, 10(4), 2397-2419.

이동훈(2011). 교사가 지각한 $\mathrm{ADHD}$ 아동의 또래, 교사, 부모 관계 특성. 재활심리연구, 18(3), 341-360.

이미아(2008). $\mathrm{ADHD}$ 아동의 사회적 유능성과 영향요인간의 관계. 특수교육학연구, 43(1), 17-35.

이성직(2013). 주의력결핍 과잉행동장애 아동을 위한 가족상담 접근에 대한 고찰 및 제안. 가족 과 상담. 3(1), 1-14.

이정은, 김춘경(2009). $\mathrm{ADHD}$ 아동의 학교기반 중재를 위한 교사교육 프로그램 구성의 예비연 구. 열린교육연구, 17(4), 343-364.

이희정, 황선영(2013). 청소년의 $\mathrm{ADHD}$ 성향이 학교폭력 가해 행동에 미치는 영향에서 학교폭 력 피해경험의 매개효과. 한국아동복지학, 42(0), 83-108.

장은진(2005). 주의력결핍 과잉행동 아동을 위한 학교기반 개입의 예비연구. 열린교육연구, 13(1), 63-84.

정계숙(1990). 학습준비도가 높은 아동과 낮은 아동의 생태학적 비교 연구: 도시와 농촌 아동을 중심으로. 유아교육연구, 10, 119-138.

정종성, 최진오(2010). 초등교사의 $\mathrm{ADHD}$ 에 대한 지식수준, $\mathrm{ADHD}$ 아동 통합에 대한 태도 및 생활지도방법 활용에 대한 분석. 특수교육저널: 이론과 실천, 11(3), 371-393.

최명선(1998). 경제위기하에서 아동의 스트레스에 영향을 미치는 생태학적 변인의 구조 분석. 석 사학위논문, 숙명여자대학교.

최연숙(2014). ADHD 학생을 경험한 초등학교 교사의 태도 구성요인에 관한 연구. 특수아동교 육연구, 16(1), 255-278.

최진오(2012). 초등학생의 $\mathrm{ADHD}$ 증상에 따른 오프라인, 온라인 학교폭력 피해수준. 특수아동 교육연구, 14(3), 191-210.

표경식, 박상학, 김상훈, 조용래, 김학렬, 문경래(2001). 도시지역 초등학생에서 주의력결핍 과잉 행동장애의 유병률. 조선대학교 의대논문집, 262.

한미현(1996). 아동의 스트레스 및 사회적지지 지각과 행동문제. 박사학위논문, 서울대학교. 황순영(2011). ADHD아동 부모의 통합학급 교사와의 협력에 대한 만족도와 방해요인 탐색. 특 수아동교육연구, 13(1), 45-61. 
American Psychiatric Association. (2013). Diagnostic and statistical manual of mental disorders (5th ed.). Washington, DC: American Psychiatric Association.

Antshel, K. M. (2005). Social skills training reconsidered: what role should peers play? $A D H D$ Report, 13(1), 1-5.

Barkley, R. A. (2006). Attention-deficit hyperactivity disorder: A handbook for diagnosis and treatment (3rd ed.). New York: Guilford.

Bronfenbrenner, U. (1979). The Ecology of human development: experiments by nature and design. Cambridge, MS: Harvard University Press.

Cantwell, D. P. (1996). Attention deficit disorder: A review of the past 10 years. Journal of the American Academy of Child and Adolescent Psychiatry, 35(8), 978-987.

Cho, S. C., Kim, B. N., Kim, J. W., Rohde, L. A., Hwang, J. W., Chungh, D. S., Shin, M. S., Lyoo, I. K., Go, B. J., Lee, S. E., \& Kim, H. W. (2009). Full syndrome and subthreshold attention-deficit/hyperactivity disorder in a Korean community sample: comorbidity and temperament findings. European Child and Adolescent Psychiatry, 18(7), 447-457.

de Boo, G. M., \& Prins, P. J. (2007). Social incompetence in children with ADHD: Possible moderators and mediators in social-skills training. Clinical Psychology Review, 271), 78-97.

Diamantopoulou, S., Henricsson, L., \& Rydell, A. M. (2005). ADHD symptoms and peer relations of children in a community sample: Examining associated problems, self-perceptions, and gender differences. International Journal of Behavioral Development, 29(5), 388-398.

Dubow, E. F., \& Ulman, D. G. (1989). Assessing social support in elementary school children: the survey of children's social support. Journal of Child clinical Psychology, 18(1), $52-64$.

DuPaul, G. J. (1991). Parent and Teacher Rating of ADHD symptoms: psychometric properties in a community-based sample. Journal of Clinical Child Psychology, 20(3), 245-253.

DuPaul, G. J., \& Weyandt, L. (2006). School-based intervention for children with attention deficit hyperactivity disorder: effects on academic, social, and behavioral functioning. International Journal of Disability, Development and Education, 53(2), 161-176.

DuPaul, G. J., Power, T. J., Anastopoulos, A. D., Reid, R., McGoey, K. E., \& Ikeda, M. J. (1997). Teacher ratings of attention-deficit/ hyperactivity disorder: factor structure 
and normative data. Psychological Assessment, 9(4), 436-444.

Fischer, M., Barkley, R. A., Smallish, L. K., \& Fletcher K. (2005). Executive Functioning in Hyperactive Children as Young Adults: Attention, Inhibition, Response Perseveration. Developmental Neuropsychology, 27(1), 107-133.

Harter, S. (1985). Manual for the social support scale for children. Denver: University of Denver. Harter, S. (2012). Emerging self-processes during childhood and adolescence. In M. R. Leary \& J. P. Tangney (Eds.), Handbook of self and identity (pp. 680-715). New York: The Guilford Press.

Hodgens, J. B., Cole, J., \& Boldizar, J. (2000). Peer-based differences among boys with ADHD. Journal of Clinical Child Psychology, 29(3), 443-452.

Holmberg, K., \& Hjern, A. (2008). Bullying and attention-deficit hyperactivity disorder in 10-year-olds in a Swedish community. Developmental Medicine and Child Neurology, 50(2), 134-138.

Hoza, B. (2007). Peer functioning in children with ADHD. Ambulatory Pediatrics, 71), 101-106. Hoza, B., Gerdes, A. C., Mrug, S., Hinshaw, S. P., Bukowski, W. M., Gold, J., Arnold, E., Abikoff, H., Conners, K., Elliott, G., Greenhill, L., Hechtman, L., Jensen, P., Kraemer, H., March, J., Newcorn, J., Severe, J., Swanson, J., Vitiello, B., Wells, K., \& Wigal, T. (2005). Peer-assessed outcomes in the multimodal treatment study of children with attention deficit hyperactivity disorder. Journal of Clinical Child \& Adolescent Psychology, 34(1), 74-86.

Huang-Pollock, C.L., Mikami, A., Pfiffner, L., \& McBurnett, K. (2009). ADHD subtype differences in motivational responsivity but not inhibitory control: Evidence from a reward-based variation of the stop signal paradigm. Journal of Clinical Child and Adolescent Psychology, 36(2), 127-136.

Jeong, Y. C., Lee, J. B., Park, H. B., Cheung, S. D., Sung, H. M., \& Sakong, J. K. (2001). Developmental changes of children with attention deficit hyperactivity disorder. Journal of the Korean Society of Biological Therapies in Psychiatry, 71), 137-146.

Kaidar, I., Wiener, J., \& Tannock, R. (2003). The attributions of children with attention-deficit/hyperactivity disorder for their problem behaviors. Journal of Attention Disorders, 6(3), 99-109.

Lewinsohn, P. M., Shankman, S. A., Gau. M., \& Klein, D. N. (2004). The prevalence and co-morbidity of subthreshold psychiatric conditions. Psychological Medicine, 34(4), 613-622. 
McDowell, D. J., \& Parke, R. D. (2009). Parental correlates of children's peer relations: an empirical test of a tripartite model. Developmental Psychology, 45(1), 224-235.

McQuade, J. D., \& Hoza, B. (2008). Peer problems in ADHD: current status and future directions. Developmental Disabilities Research Reviews, 14(4), 320-324.

Mikami, A. Y., \& Hinshaw, S. P. (2003). Buffers of peer rejection among girls with and without ADHD: the role of popularity with adults and goal-directed solitary play. Journal of Abnormal Child Psychology, 31(4), 381-397.

Mikami, A. Y., \& Hinshaw, S. P. (2006). Resilient adolescent adjustment among girls: Buffers of childhood peer rejection and Attention-deficit/hyperactivity disorder. Journal of Abnormal Child Psychology, 34(6), 823-837.

Mikami, A. Y., Lerner, M. D., \& Lun, J. (2010). Soial context influences on children's rejection by their peers. Child Development Perspectives, 4(2), 123-130.

Mikami, A. Y., Jack, A., Emeh, C. C., \& Stephens, H. F. (2010). Parental influences on children with ADHD: I. Parental behaviors associated with children's peer relationships. Journal of Abnormal Child Psychology, 38(6), 721-736.

Mikami, A. Y., Gregory, A., Allen, J. P., Pianta, R. C., \& Lun, J. (2011). Effects of a teacher professional development intervention on peer relationships in secondary classrooms. School Psychology Review, 40(3), 367-385.

Miranda, A., Presentacion, M. J., \& Soriano, M. (2002). Effectiveness of a school-based multicomponent program for the treatment of children with ADHD. Journal of Learning Disabilities, 35(6), 546-562.

Mounts, N. S. (2000). Parental management of adolescent peer relationship: What are its effects on friend selection? In Kerns, K. A., Contretras, J. M., \& Neal-Barnett, A. M. (Eds.). Family and peers: linking two social worlds. Westport, Praeger.

Murg, S., Molina, B., Hoza, B., Gerdes, A., Hinshaw, S., Hechtman, L., \& Arnold, E. (2012). Peer rejection and friendships in children with attention-deficit/hyperactivity disorder: contributions to long-term outcomes. Journal of Abnormal Child Psychology, 4Q6), 1013-1026.

Pfiffner, L. J., Villodas, M., Kaiser, N., Rooney, M., \& McBurnett, K. (2013). Educational outcomes of a collaborative school-home behavioral intervention for ADHD. School Psychology Quarterly, 28(1), 25-36.

Rohde, L. A. (2008). Is there a need to reformulate attention deficit hyperactivity disorder criteria in future nosologic classification? Child and Adolescent Psychiatry Clinics of 
North America, 172), 405-420.

Rucklidge, J. J., \& Tannock, R. (2001). Psychiatric, psychosocial, and cognitive functioning of female adolescents with ADHD. Journal of the American Academy of Child and Adolescent Psychiatry, 40(7), 530-540.

Weiss, G., \& Hechtman, L. (1993). Hyperactive children grown up: ADHD in children, adolescents and adults (2nd ed.). NY: Guilford Press.

Wiener, J., \& Mak, M. (2009). Peer victimization in children with attention-deficit /hyperactivity disorder. Psychology in the Schools, 46(2), 116-131.

Wiener, J., Malone, M., Varma, A., Markel, C., Biondic, D., Tannock, R., \& Humphiries, T. (2012). Children's perceptions of their ADHD symptoms: positive illusions, attributions, and stigma. Canadian Journal of Social Psychology, 273), 217-242.

Yoo, H. J., Cho, S. C., Ha, J., Yune, S. K., Kim, S. J., Hwang, J., Chung, A., Sung, Y. H., \& Lyoo, I. K. (2004). Attention deficit hyperactivity symptoms and Internet addiction. Psychiatry and Clinical Neurosciences, 58(5), 487-494.

\section{* 논문접수 2014년 11월 4일 / 1차 심사 2014년 12월 9일 / 게재승인 2014년 12월 16일}

* 송연주: 미국 펜실베니아 대학교에서 교육학 석사학위를 취득하였고, 부산대학교 교육학과에서 교육심리 및 상담심리로 박사학위를 취득하였다. 현재 부산대학교 교육발전연구소 전임연구원으로 재직 중이다.

*E-mail: ssong0408@gmail.com 


\section{Estimated Prevalence of ADHD Symptoms and Relationships among ADHD Symptoms, Environmental Variables, and Peer Relationships in Elementary School Students}

Song, Yeon Joo*

The purpose of this research is to estimate the prevalence of Attention Deficit Hyperactivity Disorder (ADHD) symptoms and to investigate the relationships among ADHD symptoms, environmental factors, and peer relationships in elementary school students. Prevalence for ADHD symptoms was based on teacher-reports (K-ARS) in a sample of $4^{\text {th }}, 5^{\text {th }}, 6^{\text {th }}$ grade elementary school students. In addition, relationships among ADHD symptoms, environmental variables in terms of teacher support, peer prejudice, parents-teacher relationships, and parents-peer relationships, and peer relationships were investigated. The results were follows. First, prevalence rate of ADHD symptoms was $22.32 \%$, and for gender ranged $31.51 \%$ for male and $12.64 \%$ for female students. Second, compared to non-ADHD group, ADHD symptoms group displayed lower mean scores on teacher support, parents-teacher relationships, parents-peer relationships, and peer relationships, whereas displayed higher mean scores on peer prejudice. Third, on ADHD symptoms group, teacher support, peer prejudice, parents-teacher relationships, and parents-peer relationships were the predictive variables of peer relationships. On non-ADHD group, ADHD symptoms were also the predictive variable of peer relationships. Through the study, it was revealed that children with ADHD symptoms, who did not diagnose with $\mathrm{ADHD}$, but display high level of ADHD symptoms were increasing, experienced difficulties with peer relationships, and the peer relationships should be understood within their environmental context in which they live, such as school. According to these results, findings and implications are discussed.

Key words: ADHD symptoms, prevalence, environmental context, peer relationships, elementary school students

\footnotetext{
* Researcher, Educational Development Institute, Pusan National University
} 